\title{
Predicting the Lime Demand of Arable Soils from pH Value, Soil Texture and Soil Organic Matter Content
}

\author{
Joerg Ruehlmann*, Eric Bönecke (D) and Swen Meyer (D) \\ Leibniz-Institute of Vegetable and Ornamental Crops, 14979 Großbeeren, Germany; boenecke@igzev.de (E.B.); \\ meyer.swen@igzev.de (S.M.) \\ * Correspondence: ruehlmann@igzev.de
}

check for updates

Citation: Ruehlmann, J.; Bönecke, E.; Meyer, S. Predicting the Lime Demand of Arable Soils from $\mathrm{pH}$ Value, Soil Texture and Soil Organic Matter Content. Agronomy 2021, 11, 785. https://doi.org/10.3390/ agronomy11040785

Academic Editor: Camilla Dibari

Received: 14 March 2021

Accepted: 13 April 2021

Published: 16 April 2021

Publisher's Note: MDPI stays neutral with regard to jurisdictional claims in published maps and institutional affiliations.

Copyright: (c) 2021 by the authors. Licensee MDPI, Basel, Switzerland. This article is an open access article distributed under the terms and conditions of the Creative Commons Attribution (CC BY) license (https:// creativecommons.org/licenses/by/ $4.0 /)$.

\begin{abstract}
For more than 40 years, farmers in Germany have used the fertilization recommendation schema provided by the Association of German Agricultural Investigation and Research Institutions (VDLUFA) to quantify the required lime $(\mathrm{CaO})$ demand of arable mineral soils. To be applicable as guidelines in practice, the results of 30 years of fertilization experiments that studied the correlation between crop yields and the actual soil $\mathrm{pH}$, the soil texture, and the soil organic matter (SOM) content were finally condensed into a look-up table system. However, because the original experimental data are no longer accessible, the purpose of this study is to reconstruct the interaction between the three soil parameters and their appropriate lime demands. Therefore, the class-based, stepwise approach of the look-up table system is transferred into a continuous, stepless approach using mathematical models. Under the precondition to preserve the $\mathrm{pH}-$, texture- and SOM-dependent $\mathrm{CaO}$ amounts recommended in the look-up system $(n=317)$ to the greatest extent possible, the algorithm was successful; more than $99 \%$ of their variability could be explained by the models. This adaptation helps to meet the accuracy of present-day requirements of precision farming.
\end{abstract}

Keywords: soil pH management; soil liming; sensor-based soil maps; continuous; non-class based approach

\section{Introduction}

Traditionally, agronomic input and management practices have been uniformly applied in agricultural fields considering the spatial heterogeneity of soil properties and the effects of topography. Uniform agronomic management does not take spatial variability into account. Therefore, it can be economically and environmentally inefficient [1]. Sitespecific management, as an intrinsic part of precision agriculture, contributes to increasing yield, reducing inputs, and minimizing environmental impact [2-7]. However, the benefits of site-specific management strategies are strongly dependent on the quality of the variability prediction. Basso et al. [8] reported that in many studies in which guidelines for the delineation of management zones were proposed, areas within a field that are homogeneous with respect to yield limiting factors were defined. Compared to traditional uniform-rate application methods, the use of management zone delineation techniques for variable-rate nutrient application increased farm efficiency according to Nawar et al. [9].

Based on the original methods, e.g., to estimate the lime demand of soil [10-13], lookup table systems were developed as easily applicable tools for farmers to determine the correct amounts of lime [13].

The agricultural liming recommendations for Germany are provided by the "Association of German Agricultural Investigation and Research Institutions" (VDLUFA). They are based on the results of 30 years of fertilization experiments, in which the effect of lime fertilization on soil $\mathrm{pH}\left(\mathrm{CaCl}_{2}\right)$ and crop yield under consideration of soil texture and $\mathrm{SOM}$ content was studied $[14,15]$. To be applicable as a liming guide in practice, the results were condensed to the VDLUFA look-up table system $[14,16]$. These tables provide the lime demand of arable soils and grasslands depending on (i) the actual $\mathrm{pH}$ (considered in steps of $0.1 \mathrm{pH}$ units), (ii) the present soil texture (divided into five classes of mineral soils and 
one class for organic soils) and (iii) the SOM content (separated into four classes). Farmers can use these tables without calculations and without special expert knowledge to assess the lime demand for their fields. Over the last 40 years, the VDLUFA look-up table system has served the agricultural needs of lime fertilization very well but has to be considered very rough, especially in relation to new results of soil texture mapping [17-19]. As was shown in these studies, soil data can now be determined very accurately and with a high degree of spatial accuracy using on-the-go soil sensors and digital soil mapping techniques. However, when using the conventional VDLUFA look-up table system with these new input data for lime fertilization, much of the input information from the new soil texture and the SOM mapping systems is lost because the classes of this system are rather coarse. Meyer et al. [19] reported a data acquisition strategy to generate digital soil texture and SOM maps in a precision farming context, combining spatially high-resolution soil sensor data and point reference samples for soil texture and SOC. Nevertheless, this information needs to be implemented in a finer lime recommendation system with a continuous scale, rather than a coarse class-based system (see Section 2.1). Unfortunately, the original experimental data that were used to derive the VDLUFA look-up table system are no longer available, which precludes a first-hand investigation.

Accompanied by the development of adequate soil sensor systems to detect the spatial heterogeneity of soil properties [20] and by the progress in agricultural machinery responding to this heterogeneity [21,22], decision-making rules must also be adapted in order to meet the accuracy of these new requirements of precision farming.

The main objective of this paper was therefore to adapt the German VDLUFA approach to the current requirements of precision farming. To achieve this, the relationships between the lime demand $(\mathrm{CaO})$ and the three soil parameters $(\mathrm{pH}$, soil texture, SOM) were reconstructed from the class-based, stepwise look-up table system and transferred to a continuous, stepless approach.

\section{Materials and Methods}

\subsection{Guidelines to Predict the Soil's Lime Demand as Recommended by VDLUFA}

2.1.1. Description of the Guidelines

The prediction of the lime requirement of the soils according to the German VDLUFA guidelines [14,15] is based on $\mathrm{pH}$ measurements, which have been obtained from 30 years in fertilization experiments, especially on acidic soils [15]. As a result, the $\mathrm{pH}$ ranges for optimum plant growth could be predicted. The factors of soil texture (clay content), SOM content and crop type were identified as particularly relevant for the definition of optimum $\mathrm{pH}$ ranges. Furthermore, $\mathrm{CaO}$ amounts that need to be fertilized to achieve the optimum range of soil $\mathrm{pH}$ were derived. This relates to a four-year crop rotation cycle, where the soil analysis should be repeated every four years. To transfer these experimental results in an appropriate structure that is useful as a guideline to calculate the $\mathrm{CaO}$ demand in agricultural practice, three classifications were made:

i. Classification according to the lime supply statuses

Five different lime supply levels (A to E) were defined for arable lands (Table 1). In classes $\mathrm{A}$ and $\mathrm{B}$ the $\mathrm{pH}$ values are below the optimum. Here, both the soil structure and nutrient availability will be negatively influenced, the plant availability of heavy metals is increased and the yield losses range between 20-40\% [15]. Therefore, high to medium amounts of $\mathrm{CaO}$ fertilizer (class $\mathrm{A}-\mathrm{B}$ ) are recommended. In class $\mathrm{C}$, the optimum $\mathrm{pH}$ range related to maximum yields is present. Only the minimum lime amounts are required to maintain the $\mathrm{pH}$ in the optimum range. For classes $\mathrm{D}$ and $\mathrm{E}$, the $\mathrm{pH}$ values are above the optimum and can, for example, also lead to a lower nutrient availability, and crop yields may decline by 5-10\% [15]. Thus, liming or any use of fertilizers that might react physio-chemically to alkaline conditions should be omitted [16]. 
Table 1. Soil $\mathrm{pH}$ and lime requirement classes of the Association of German Agricultural Investigation and Research Institutions (VDLUFA) [23].

\begin{tabular}{|c|c|c|}
\hline $\begin{array}{l}\text { pH Class/Lime Supply } \\
\text { Status }\end{array}$ & Description & Lime Requirement \\
\hline A-very low & $\begin{array}{l}\text { Conditions: Significant impairment of soil structure and nutrient } \\
\text { availability, very high lime requirement, significant yield losses in } \\
\text { almost all crops up to complete yield loss, strongly increased plant } \\
\text { availability of heavy metals in the soil. } \\
\text { Action: Liming takes precedence over other fertilization measures } \\
\text { regardless of the crop. }\end{array}$ & high \\
\hline B-low & $\begin{array}{l}\text { Conditions: Still sub-optimal conditions for soil structure and } \\
\text { nutrient availability, high lime requirement, mostly still significant } \\
\text { yield losses in lime-demanding crops, increased plant availability of } \\
\text { heavy metals in the soil. } \\
\text { Action: Within the crop rotation, preferential liming for } \\
\text { lime-demanding crops. }\end{array}$ & medium \\
\hline C-optimal & $\begin{array}{l}\text { Conditions: Optimal conditions for soil structure and nutrient } \\
\text { availability, low lime requirement, hardly or no additional yield } \\
\text { through liming. } \\
\text { Action: Within the crop rotation, liming for lime-demanding crops. }\end{array}$ & low \\
\hline D-high & $\begin{array}{l}\text { Conditions: The soil } \mathrm{pH} \text { status is higher than intended, no lime } \\
\text { requirement. } \\
\text { Action: Omission of lime application }\end{array}$ & no liming \\
\hline E-very high & $\begin{array}{l}\text { Conditions: The soil } \mathrm{pH} \text { status is much higher than intended and } \\
\text { can negatively affect nutrient availability as well as crop yield and } \\
\text { quality. } \\
\text { Action: No liming or use of fertilizers that, as a result of } \\
\text { physiochemical or chemical reactions, acidify the soil. }\end{array}$ & $\begin{array}{l}\text { no liming and no use of } \\
\text { fertilizers that react to } \\
\text { alkaline conditions }\end{array}$ \\
\hline
\end{tabular}

\section{ii. Classification according to the soil texture}

In Germany, two different soil texture classification systems are mainly applied. The classification system of the German Soil Science Society (DBG) distinguishes 31 soil texture classes and is widely used in a scientific context. Rather than being applied in agricultural practice, the soil texture classification system of the VDLUFA is divided into five soil classes of mineral soils (TEX1-5) varying in their ranges of clay content $\left(\mathrm{kg} \mathrm{kg}^{-1}\right)$ : TEX1 $\leq 0.05$, TEX2 $>0.5-0.12$, TEX3 $>0.12-0.17$, TEX4 $>0.17-0.25$, TEX5 $>0.25$.

\section{iii. Classification according to the SOM}

Four SOM classes (SOM1-4) are distinguished by varying in their SOM content [g $\mathrm{kg}^{-1}$ ]: SOM1 $\leq 40$, SOM2 > 40-80, SOM3 > 80-150, and SOM4 > 150-300. Soils with a SOM content $>300 \mathrm{~g} \mathrm{~kg}^{-1}$ are classified into a separate soil group and excluded from our presented contribution.

2.1.2. Dependency of the Lime Supply Status and of the Soil Lime Demand on Soil Texture, SOM Content and Soil $\mathrm{pH}$

As mentioned in the description of the VDLUFA guidelines (see Introduction), the factors soil texture and the SOM content were identified as particularly relevant for the definition of optimum $\mathrm{pH}$ ranges, as well as of the $\mathrm{CaO}$ fertilizer amounts necessary to achieve the optimum soil $\mathrm{pH}$ range. The VDLUFA classification of the lime supply statuses (A to E) with pH ranges for the soil texture classes (TEX1 to TEX5) and the SOM classes (SOM1 to SOM4) are shown in Figure 1. The reported $\mathrm{CaO}$ application amounts necessary to reach the optimum lime supply as a function of the five soil texture classes, four SOM classes and the determined $\mathrm{pH}$ values are shown in Figure 2. 


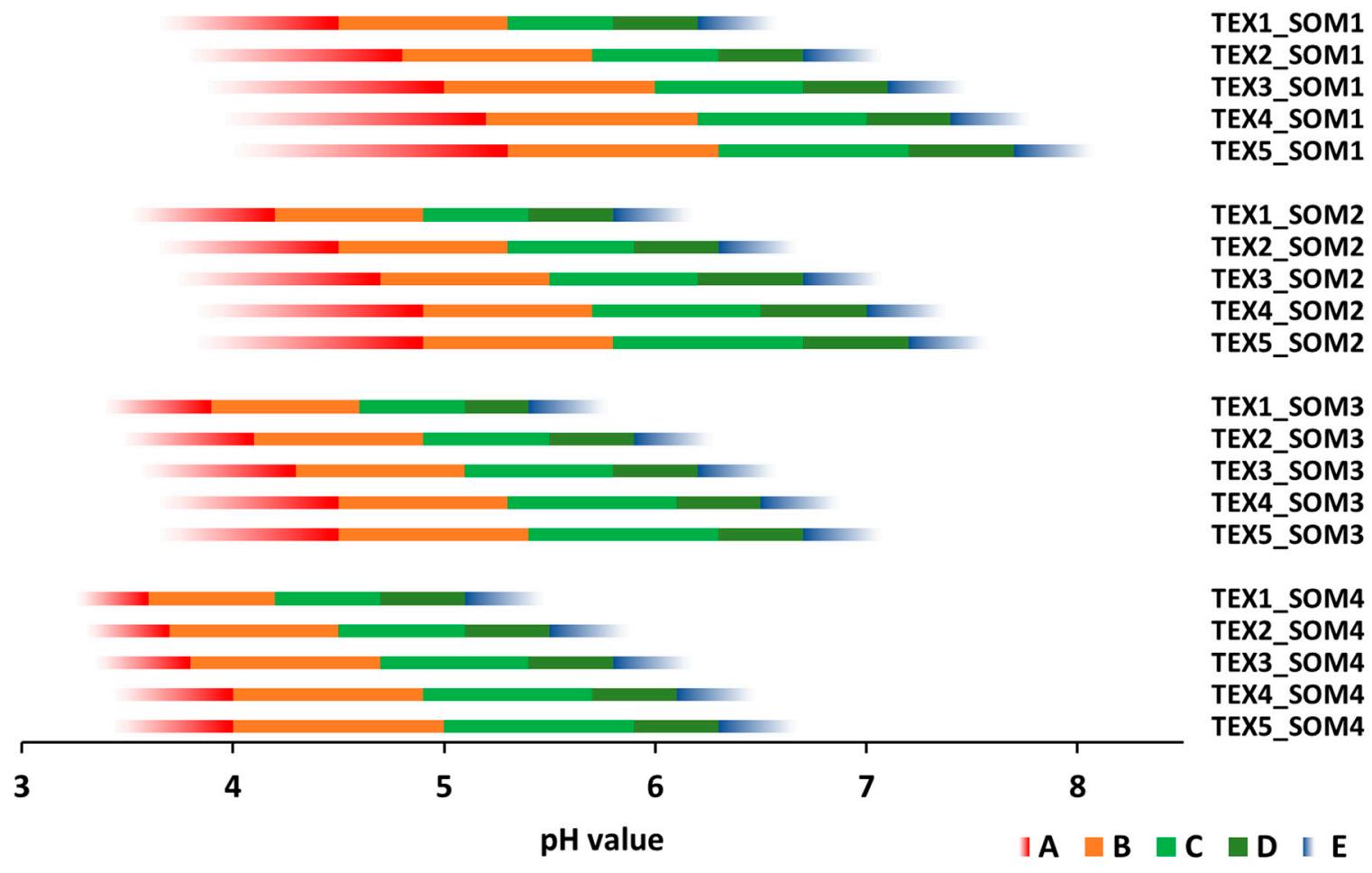

Figure 1. $\mathrm{pH}$ ranges of the lime supply statuses A-E (compare Table 1) in relation to the soil texture classes (TEX1-5) and the soil organic matter (SOM) classes (SOM1-4).

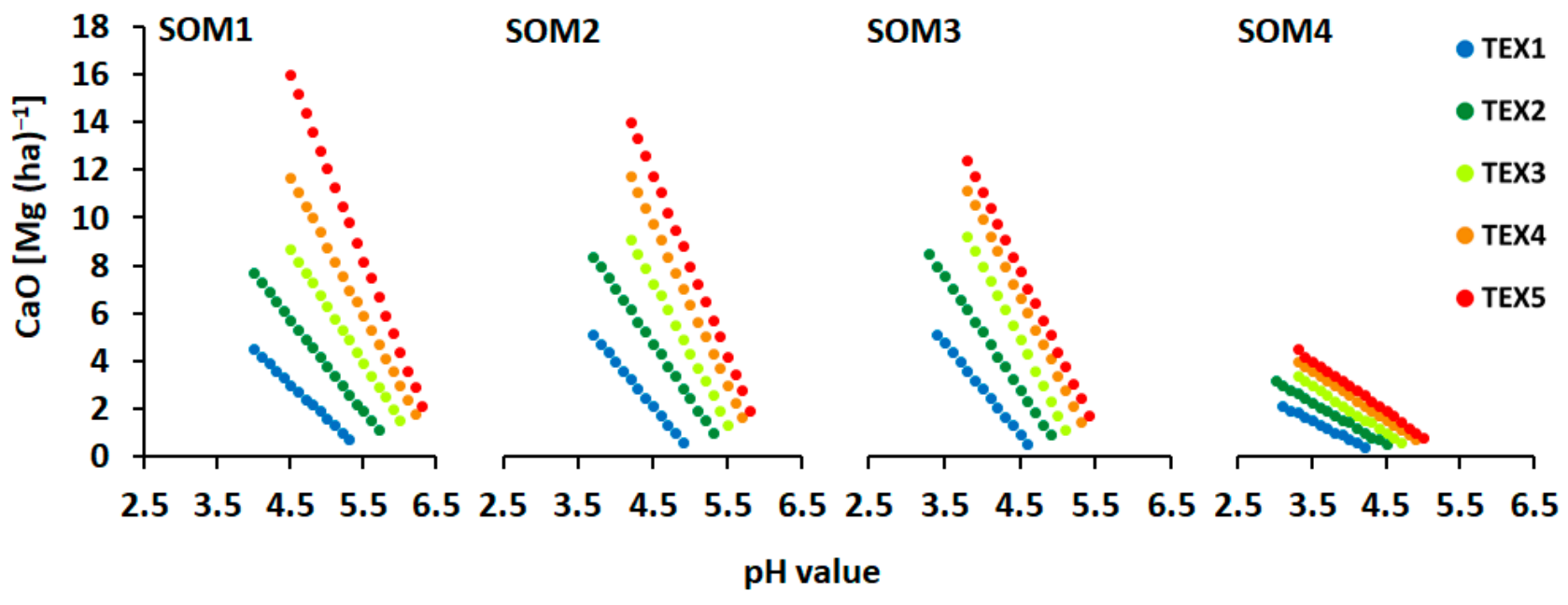

Figure 2. $\mathrm{CaO}$ amounts recommended by VDLUFA to increase the $\mathrm{pH}$ value from suboptimal statuses to the optimum $\mathrm{pH}$ ranges, depending on the SOM and soil texture classes. The given $\mathrm{pH}$ ranges correspond to the lime supply statuses $\mathrm{A}$ and B (compare Table 1 and Figure 1). The recommendation is usually related to a period of 4 years (one crop rotation).

With regard to the lime supply conditions shown in Figure 1, the following dependencies can be derived:

i. With an increasing clay content (TEX1 $\rightarrow$ TEX5), the ranges of the lime supply statuses (A-E) shift towards higher $\mathrm{pH}$ values and

ii. With an increasing SOM content (SOM1 $\rightarrow$ SOM4), the ranges of the lime supply statuses (A-E) shift towards lower $\mathrm{pH}$ values.

The relationships between the soil $\mathrm{pH}$ value and the recommended amount of $\mathrm{CaO}$ differ for the following three situations: 
i. Lime supply statuses $\mathrm{A}$ and $\mathrm{B}$ : the linear relationships between $\mathrm{pH}$ and the $\mathrm{CaO}$ demand as per each soil texture and SOM combination (Figure 2),

ii. Lime supply status $\mathrm{C}$ : fixed lime recommendations subdivided for the 20 soil texture and SOM combinations as shown in Figure 1 (Figure 3), and

iii. Lime supply statuses D and E: no lime demand

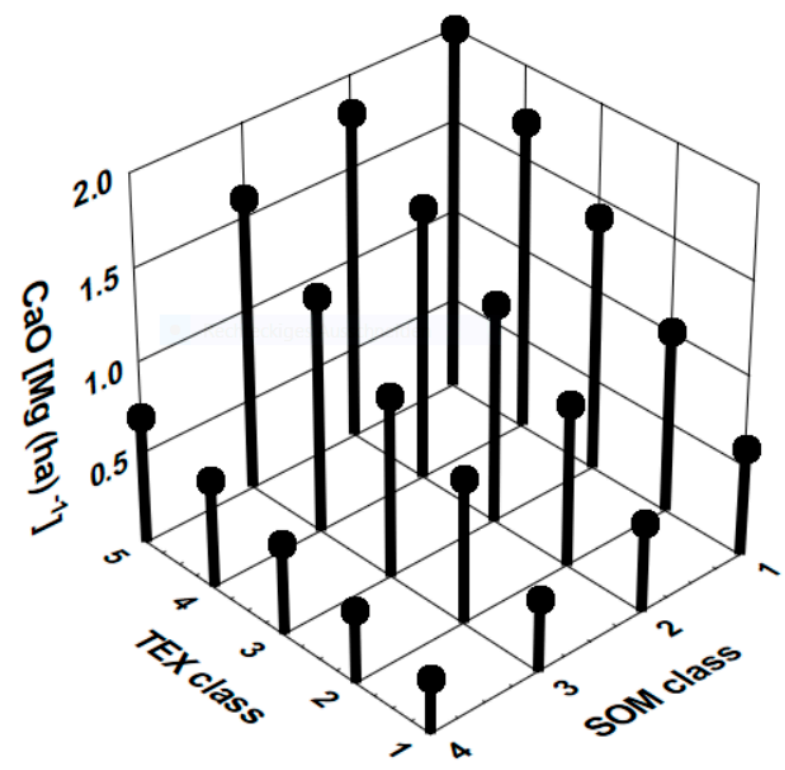

Figure 3. $\mathrm{CaO}$ amounts to maintain the optimum $\mathrm{pH}$ range (lime supply status $\mathrm{C}$ ) depending on the soil texture classes and soil organic matter classes. These VDLUFA recommendations refer to a crop rotation of 4 years.

Under supply level statuses A and B, the $\mathrm{pH}$ is suboptimal. Therefore, the recommended amount of lime should increase the soil $\mathrm{pH}$ up to the optimum lime supply status C. As shown in Figure 2, the slopes of the linear functions decline more strongly with an increasing clay content (TEX1 $\rightarrow$ TEX5), while the intercepts increase. Under increasing SOM contents (SOM1 $\rightarrow$ SOM4), the mentioned behavior of the slopes and intercepts is opposed. Therefore, the task was to substitute the five soil texture classes and the four SOM classes with continuous scaled measures.

Within lime supply level $\mathrm{C}$, the optimum $\mathrm{pH}$ range is already present. The recommended lime supplies preserve this level within a four-year crop rotation (Figure 1). However, the recommended $\mathrm{CaO}$ amounts by the VDLUFA approach are not further differentiated regarding the soil's $\mathrm{pH}$ but are for each of the 20 combinations of soil texture and SOM class (Figure 3). The $\mathrm{CaO}$ amounts shown in Figure 3 are always lower than the lowest $\mathrm{CaO}$ amounts recommended for lime supply status $\mathrm{B}$ for each of the 20 combinations, but always higher than zero.

To avoid excessive application rates, the recommended maximum $\mathrm{CaO}$ amounts $[\mathrm{Mg}$ $\mathrm{ha}^{-1}$ ] of a single application rate are merely soil texture dependent and vary as follows: TEX1 $=2.8, \mathrm{TEX} 2=4.2, \mathrm{TEX} 3=5.6, \mathrm{TEX} 4=7.0$ and TEX $5=8.4$. When the recommended $\mathrm{CaO}$ amounts exceed these maxima, fertilization should be split into two rates and applied separately in time.

Under lime supply levels $\mathrm{D}$ and $\mathrm{E}$, the $\mathrm{pH}$ values exceed the optimum $\mathrm{pH}$ range, and no liming is recommended to change the $\mathrm{pH}$ and achieve lime supply status $\mathrm{C}$.

\subsection{From the Stepwise, Class-Based VDLUFA Approach to a Stepless, Continuously Scaled Approach}

Since the abovementioned VDLUFA approach is based on classified factors (five soil texture classes and four soil organic matter classes), transformation into continuously scaled soil textures and SOM contents is required. 
The soil texture classification systems applied in Germany are mainly those of the German Soil Science Society (DBG) (31 soil texture classes) and the VDLUFA classification system (five soil texture classes). While the former is mainly used in a scientific context considering the three particle size fractions: clay $\left(0-0.002 \times 10^{-3} \mathrm{~m}\right)$, silt $(0.002-0.063 \times$ $10^{-3} \mathrm{~m}$ ) and sand $\left(0.063-2 \times 10^{-3} \mathrm{~m}\right.$ ), the latter is solely based on the clay (or clay + fine silt) content and instead used in a practical background. However, to apply a continuously scaled soil texture measure under equal consideration of the clay, silt and sand fractions, this study refers to the geometric mean particle size diameter (MPD) according to Shiozawa and Campbell [24] as follows:

$$
\mathrm{MPD}=\exp \sum m_{i} \ln \left(d_{i}\right)
$$

where MPD is given in $\left[10^{-3} \mathrm{~m}\right], m_{i}$ is the mass fraction of the particle size class $i\left[\mathrm{~kg} \mathrm{~kg}^{-1}\right]$, and $d_{i}$ is the associated geometric mean diameter $\left[10^{-3} \mathrm{~m}\right]$. As suggested by Shirazi et al. [25], the lower limit of the clay size fraction was set to $1 \times 10^{-8} \mathrm{~m}$. The geometric means that correspond to the particle size class ranges of the clay, silt and sand fractions were $1.41 \times 10^{-7} \mathrm{~m}, 1.12 \times 10^{-5}$ and $3.55 \times 10^{-4} \mathrm{~m}$, respectively.

In the next step, the MPDs are calculated for the corresponding centroids of the polygons, as they represent the sand, silt and clay contents of the 31 DBG soil texture classes (Table 2). The classes of both the VDLUFA and DBG systems are shown in Figure 4.

Table 2. Clay, silt, and sand contents $\left[\mathrm{kg} \mathrm{kg}^{-1}\right]$ and the corresponding mean particle diameters (MPDs) $\left[10^{-3} \mathrm{~m}\right]$ of the $31 \mathrm{DBG}$ soil texture classes.

\begin{tabular}{|c|c|c|c|c|}
\hline \multirow{2}{*}{$\begin{array}{c}\text { Soil Texture } \\
\text { Classes }\end{array}$} & \multicolumn{3}{|c|}{ Coordinate Centers of the Polygons } & \multirow[b]{2}{*}{ MPD } \\
\hline & Clay & Silt & Sand & \\
\hline $\mathrm{Tt}$ & 0.766 & 0.117 & 0.117 & 0.0006 \\
\hline Tu2 & 0.550 & 0.375 & 0.075 & 0.0013 \\
\hline $\mathrm{Tl}$ & 0.550 & 0.225 & 0.225 & 0.0022 \\
\hline Tu3 & 0.363 & 0.563 & 0.074 & 0.0030 \\
\hline Tu4 & 0.284 & 0.683 & 0.033 & 0.0036 \\
\hline Ts2 & 0.550 & 0.075 & 0.375 & 0.0037 \\
\hline Lt3 & 0.400 & 0.400 & 0.200 & 0.0039 \\
\hline Ut4 & 0.210 & 0.720 & 0.070 & 0.0057 \\
\hline $\mathrm{Lu}$ & 0.235 & 0.575 & 0.190 & 0.0077 \\
\hline Ut3 & 0.144 & 0.753 & 0.103 & 0.0085 \\
\hline Lt2 & 0.300 & 0.400 & 0.300 & 0.0085 \\
\hline Lts & 0.350 & 0.225 & 0.425 & 0.0105 \\
\hline Ut2 & 0.100 & 0.775 & 0.125 & 0.0112 \\
\hline $\mathrm{Uu}$ & 0.040 & 0.880 & 0.080 & 0.0124 \\
\hline Ts3 & 0.400 & 0.075 & 0.525 & 0.0120 \\
\hline Ls2 & 0.210 & 0.450 & 0.340 & 0.0145 \\
\hline Uls & 0.125 & 0.575 & 0.300 & 0.0183 \\
\hline Ls3 & 0.210 & 0.350 & 0.440 & 0.0205 \\
\hline Ts4 & 0.300 & 0.075 & 0.625 & 0.0262 \\
\hline Us & 0.040 & 0.650 & 0.310 & 0.0275 \\
\hline Slu & 0.125 & 0.450 & 0.425 & 0.0282 \\
\hline Ls4 & 0.210 & 0.225 & 0.565 & 0.0315 \\
\hline S14 & 0.145 & 0.250 & 0.605 & 0.0481 \\
\hline St3 & 0.210 & 0.075 & 0.715 & 0.0529 \\
\hline Su4 & 0.040 & 0.450 & 0.510 & 0.0549 \\
\hline $\mathrm{Sl} 3$ & 0.100 & 0.250 & 0.650 & 0.0684 \\
\hline Su3 & 0.040 & 0.325 & 0.635 & 0.0845 \\
\hline $\mathrm{S} 12$ & 0.065 & 0.175 & 0.760 & 0.1166 \\
\hline St2 & 0.110 & 0.050 & 0.840 & 0.1262 \\
\hline $\mathrm{Su} 2$ & 0.025 & 0.175 & 0.800 & 0.1595 \\
\hline Ss & 0.025 & 0.050 & 0.925 & 0.2456 \\
\hline
\end{tabular}




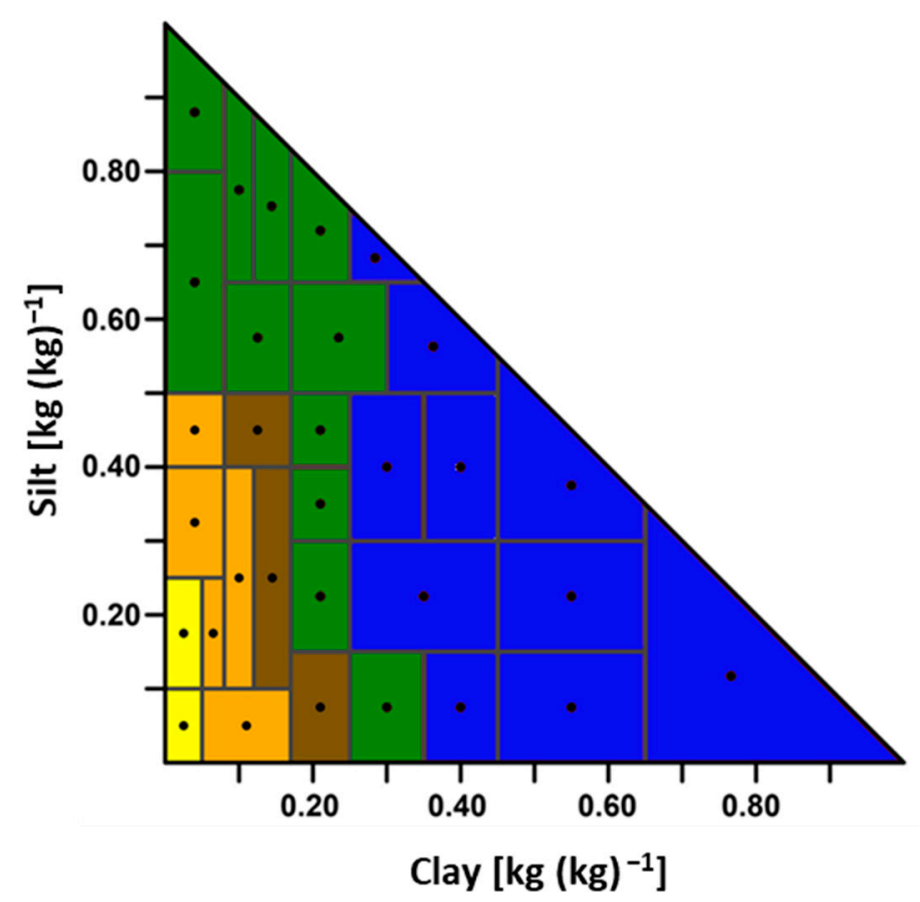

Figure 4. Soil texture classes of VDLUFA (TEX1 = yellow, TEX2 = ochre yellow, TEX3 = brown, TEX4 = green, TEX5 = blue) and 31 German Soil Science Society (DBG) soil texture classes (polygons with labeled centroid points (black dots)) as related to the clay and silt contents.

Finally, the MPDs of the five VDLUFA soil groups are calculated from the corresponding arithmetic means of the DBG MPDs that lie within the uniform-colored areas of the respective VDLUFA soil groups (Figure 4). The five VDLUFA MPDs $\left[10^{-3} \mathrm{~m}\right]$ are TEX1 $=0.203$, TEX2 $=0.091$, TEX3 $=0.042$, TEX $4=0.017$ and TEX5 $=0.005$.

Regarding the SOM classification, SOM classes 1-4 needed to be transferred into a continuously scaled measure as well. To calculate the corresponding continuous function, the arithmetic means of the abovementioned class ranges $\left[\mathrm{g} \mathrm{kg}^{-1}\right]$ : SOM1 $=20, \mathrm{SOM} 2=60$, $\mathrm{SOM} 3=115$, and SOM $4=225$ were used.

Applying this procedure allows us to characterize the five VDLUFA soil texture groups by their MPD and the four SOM groups by their mean SOM content. Based on these measures, the effects of the soil texture and the SOM could be calculated continuously for the lime supply statuses and the soil lime demand.

Aiming at the optimal lime supply status and going along with the stepless principles mentioned above, the task was to generate a continuously differentiated $\mathrm{CaO}$ determination that depends on the $\mathrm{pH}$ values within the lime supply levels $\mathrm{A}$ and $\mathrm{B}$ and that considers the $\mathrm{pH}$ range of lime supply status $\mathrm{C}$. The latter was intended to the following manner: the lime recommendation should decrease linearly, beginning with the lowest $\mathrm{CaO}$ amount recommended in lime supply status B ( $\mathrm{CaOmin} B)$, down to zero where lime supply status $\mathrm{D}$ is reached.

\subsection{Models and Statistics}

Mathematical models were used to describe the lime supply statuses and the lime demand of the soil in relation to the MPD and mean SOM contents. The models were fitted with the software TableCurve 3D version 4.0 (SYSTAT). This surface fitting software package fits and ranks numerous equations automatically and finds the "ideal model" for any 3D data. The independent variables of our models were the MPD of the five texture classes and the mean SOM content of the four SOM classes, as mentioned above.

To determine the boundaries between the lime supply levels (A/B, B/C, C/D and $\mathrm{D} / \mathrm{E})$, the upper limits of the $\mathrm{pH}$ ranges of each lime supply level (pHmax_A-D) were 
chosen to fit the multidimensional mathematical models (Figure 1). The lime supply level $\mathrm{E}$ is $>$ pHmax_D.

As described in Figure 2, 20 combinations between the five textures and the four SOM classes can be obtained to determine the lime demand according to VDLUFA. For each combination, the relationship between the observed $\mathrm{pH}\left(\mathrm{pH}_{\mathrm{obs}}\right)$ and the required lime demand $(\mathrm{CaO})$ can be described with a simple linear function:

$$
\mathrm{CaO}=m-n \mathrm{pH}_{\text {obs }}
$$

where $m$ is the intercept and $n$ the slope. Both $m$ and $n$ were assumed to be dependent on the soil texture and SOM. Therefore, first the 20 intercepts and then the 20 slopes were fitted in relation to the mean particle diameter MPD and the mean SOM content according to the respective classes.

The criterion for selecting the "ideal model" was that the function must be continuouswithout local minima and maxima within the data range. Among these functions, the function with the best fit (highest $R^{2}$ ) was selected. The aim of this procedure was to predict the lime supply statuses and the soil lime demand as exact and as close as possible to the class-based VDLUFA approach. Hence, the best model results should provide almost identical values compared to the original VDLUFA approach in order to avoid discrepancies, e.g., when agricultural service providers or farmers compare the outputs of our stepless approach with the VDLUFA look-up table system. Therefore, reducing the number of fitted model parameters and testing their level of significance were not criteria for selecting the respective model.

The algorithm to determine $\mathrm{CaO}$ amounts as stepless approach is provided as $\mathrm{R}$ script of the free software environment for statistical computing and graphics $\mathrm{R}$ (version 4.0.2) [26] in the Supplementary Material.

\section{Results}

\subsection{Predicting the Lime Supply Status of Soil}

As mentioned in Section 2.1, the relationships between the soil $\mathrm{pH}$ and the recommended amount of $\mathrm{CaO}$ may differ if the present lime supply status is suboptimal (A or B), optimal (C) or exceeded (D or E). Therefore, the lime supply status as related to the MPDs and mean SOM contents (Figure 5) must be predicted first. The three-dimensional surfaces shown represent the boundaries of the lime supply levels (A/B, B/C, C/D and D/E) based on the maximum $\mathrm{pH}$ values of the lime supply levels $\mathrm{A}-\mathrm{D}$. The mathematical models that describe the three-dimensional relationships between the upper $\mathrm{pH}$ limits, the MPDs $(x)$ and mean SOM contents $(y)$ are given in Equations (3)-(6).

$$
\begin{aligned}
& \text { pHmax_A }=a+b * \ln (x)+c * y+d *(\ln (x))^{2}+e * y^{2}+f * y * \ln (x)+g \\
& *(\ln (x))^{3}+h * y^{3}+i * y^{2} * \ln (x)+j * y \\
& \text { pHmax_B }=a+b * x+c * y+d * x^{2}+e * y^{2}+f * x * y+g * x^{3}+h * y^{3}+i \\
& * x * y^{2}+j * x^{2} * y \\
& \mathrm{pHmax} \_\mathrm{C}=\frac{\left(a+b * x+c * x^{2}+d * y+e * y^{2}+f * y^{3}\right)}{\left(1+g * x+h * x^{2}+i * x^{3}+j * y\right)} \\
& \text { pHmax_D }=a+b * \ln (x)+c * y+d *(\ln (x))^{2}+e * y^{2}+f * y * \ln (x)+g
\end{aligned}
$$

where pHmax_(A-D) are the upper limits of the $\mathrm{pH}$ range for each lime supply status A-D, $a-j$ are fitting coefficients. 

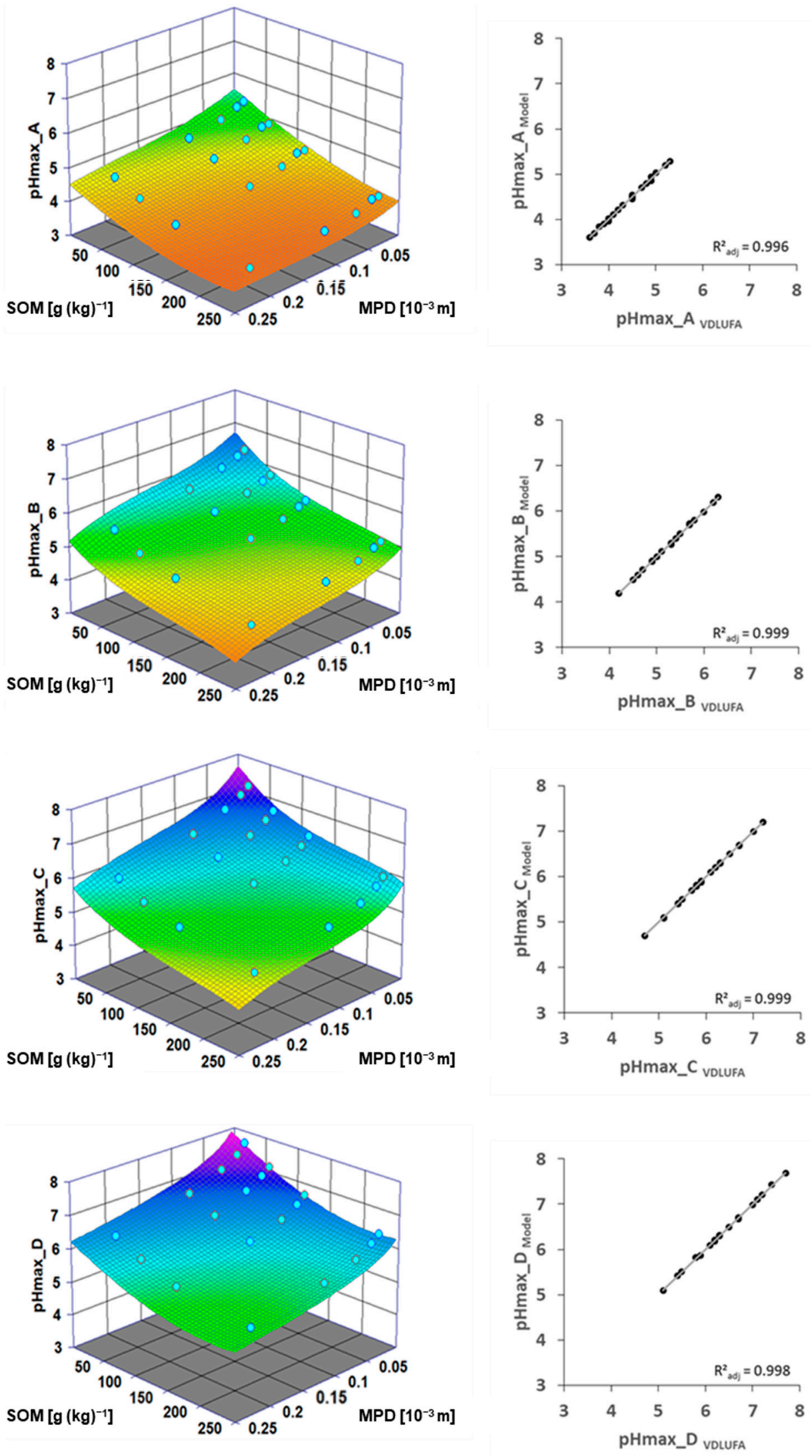

Figure 5. Left: Upper pH limits of the lime supply statuses (pHmax_A-D) as used by the VDLUFA approach (dots) and calculated according to Equations (3)-(6) (surfaces), always in relation to the soil organic matter (SOM) content and the mean particle diameter (MPD). Right: maximum pH values as predicted by Equations (3)-(6) (pHmax_A-D Model) vs. the observed $\mathrm{pH}$ values by the VDLUFA approach (pHmax_A-D VDLUFA). 
The adjusted coefficients corresponding to the models are then listed in Table 3. The models were able to describe these continuous relationships almost perfectly $\left(R^{2}>0.99\right.$ in each case) when the predicted values were compared with those of the VDLUFA approach.

Table 3. Fitted coefficients and their standard errors (in parentheses) of the mathematical models, as shown in Equations (3)-(6).

\begin{tabular}{|c|c|c|c|c|}
\hline \multirow{2}{*}{$\begin{array}{c}\text { Fitted } \\
\text { Coefficient }\end{array}$} & \multicolumn{4}{|c|}{ Dependent Variable } \\
\hline & pHmax_A ${ }^{1}$ & pHmax_B ${ }^{1}$ & pHmax_C ${ }^{1}$ & pHmax_D ${ }^{1}$ \\
\hline \multirow[t]{2}{*}{$\mathbf{a}$} & 4.13 & 6.69 & 7.64 & 4.87 \\
\hline & $\left(1.85 \times 10^{-1}\right)$ & $\left(2.19 \times 10^{-2}\right)$ & $\left(2.22 \times 10^{-2}\right)$ & $\left(1.38 \times 10^{-1}\right)$ \\
\hline \multirow[t]{2}{*}{$\mathbf{b}$} & $-2.37 \times 10^{-1}$ & $-1.17 \times 10$ & $1.08 \times 10$ & -1.15 \\
\hline & $\left(1.75 \times 10^{-1}\right)$ & $\left(7.19 \times 10^{-1}\right)$ & $(5.58)$ & $\left(1.30 \times 10^{-1}\right)$ \\
\hline \multirow[t]{2}{*}{ c } & $-5.17 \times 10^{-3}$ & $-1.81 \times 10^{-2}$ & $-1.03 \times 10$ & $-8.26 \times 10^{-3}$ \\
\hline & $\left(1.90 \times 10^{-3}\right)$ & $\left(8.02 \times 10^{-4}\right)$ & $(1.66 \times 10)$ & $\left(1.41 \times 10^{-3}\right)$ \\
\hline \multirow[t]{2}{*}{ d } & $7.34 \times 10^{-2}$ & $6.31 \times 10$ & $-3.04 \times 10^{-2}$ & $-1.33 \times 10^{-1}$ \\
\hline & $\left(5.32 \times 10^{-2}\right)$ & $(9.56)$ & $\left(3.28 \times 10^{-3}\right)$ & $\left(3.96 \times 10^{-2}\right)$ \\
\hline \multirow[t]{2}{*}{ e } & $5.31 \times 10^{-6}$ & $7.94 \times 10^{-5}$ & $1.05 \times 10^{-4}$ & $9.51 \times 10^{-6}$ \\
\hline & $\left(1.69 \times 10^{-5}\right)$ & $\left(8.53 \times 10^{-6}\right)$ & $\left(1.02 \times 10^{-5}\right)$ & $\left(1.26 \times 10^{-5}\right)$ \\
\hline \multirow[t]{2}{*}{ f } & $1.72 \times 10^{-3}$ & $1.74 \times 10^{-2}$ & $-1.95 \times 10^{-7}$ & $1.46 \times 10^{-3}$ \\
\hline & $\left(5.06 \times 10^{-4}\right)$ & $\left(3.77 \times 10^{-3}\right)$ & $\left(2.55 \times 10^{-8}\right)$ & $\left(3.77 \times 10^{-4}\right)$ \\
\hline \multirow[t]{2}{*}{ g } & $1.34 \times 10^{-2}$ & $-1.63 \times 10^{-2}$ & 4.28 & $-4.79 \times 10^{-3}$ \\
\hline & $\left(5.09 \times 10^{-3}\right)$ & $(3.22 \times 10)$ & $\left(7.76 \times 10^{-1}\right)$ & $\left(3.79 \times 10^{-3}\right)$ \\
\hline \multirow[t]{2}{*}{ h } & $3.00 \times 10^{-8}$ & $-1.39 \times 10^{-7}$ & $-1.49 \times 10$ & $3.54 \times 10^{-8}$ \\
\hline & $\left(4.66 \times 10^{-8}\right)$ & $\left(2.41 \times 10^{-8}\right)$ & $(1.97)$ & $\left(3.47 \times 10^{-8}\right)$ \\
\hline \multirow[t]{2}{*}{$\mathbf{i}$} & $-9.94 \times 10^{-8}$ & $-5.60 \times 10^{-5}$ & $3.62 \times 10$ & $-1.83 \times 10^{-6}$ \\
\hline & $\left(1.15 \times 10^{-6}\right)$ & $\left(1.08 \times 10^{-5}\right)$ & (7.56) & $\left(8.60 \times 10^{-7}\right)$ \\
\hline \multirow[t]{2}{*}{$\mathbf{j}$} & $1.78 \times 10^{-4}$ & $7.68 \times 10^{-3}$ & $-1.55 \times 10^{-3}$ & $9.13 \times 10^{-5}$ \\
\hline & $\left(5.87 \times 10^{-5}\right)$ & $\left(1.20 \times 10^{-2}\right)$ & $\left(4.00 \times 10^{-4}\right)$ & $\left(4.38 \times 10^{-5}\right)$ \\
\hline
\end{tabular}

${ }^{1} \mathrm{pHmax} \_\mathrm{A}-\mathrm{D}=$ upper limits of the $\mathrm{pH}$ range for each lime supply status A-D.

\subsection{Predicting the Lime Demand of Soils for Different Lime Supply Statuses}

Regarding lime supply statuses A and B, the 20 linear relationships between the soil $\mathrm{pH}$ and the lime demand are dependent on soil texture and SOM, as shown in Figure 2. Here, both the intercepts and the slopes of the corresponding linear relationships are related to the MPDs of the five VDLUFA soil texture classes and to the mean SOM contents of the four VDLUFA SOM classes (Figure 6). 

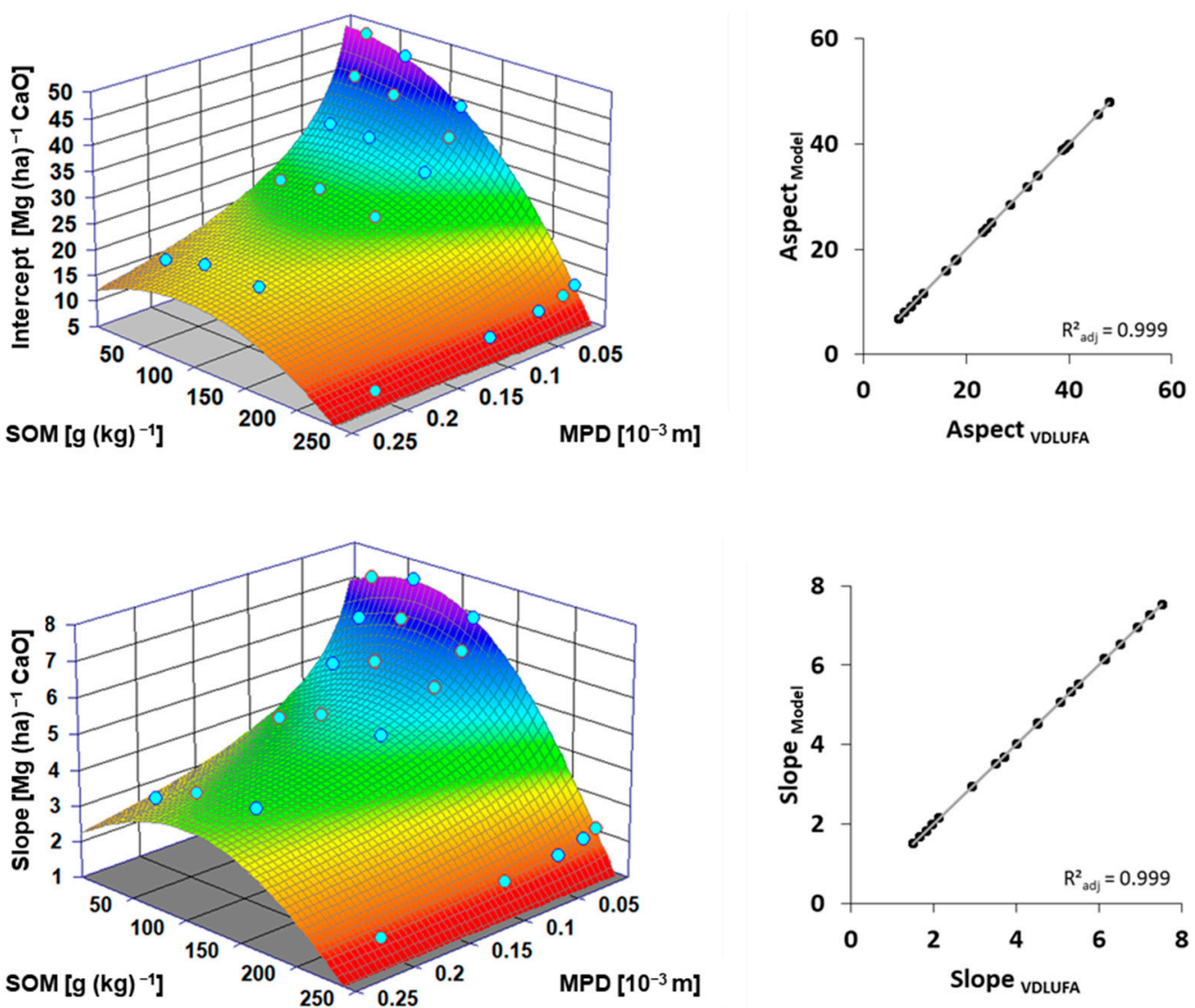

Figure 6. Left: Intercepts (top) and slopes (bottom) of the dependency of the CaO demand of soils on the soil $\mathrm{pH}$, mean particle diameter (MPD) and soil organic matter (SOM) content as calculated based on the linear relationships given by the VDLUFA approach and shown in Figure 2 (dots) and calculated according to Equations (7) and (8) (surfaces). Right: Intercepts (top) and slopes (bottom) calculated by Equations (7) and (8), respectively, predicted (Model) vs. observed (VDLUFA) approach.

The mathematical models that describe the three-dimensional relationships between the intercepts or slopes, the MPDs $(x)$ and mean SOM contents $(y)$ are given in Equations (7)-(8).

$$
\begin{gathered}
\text { intercept }=\frac{\left(a+c * \ln (x)+e * y+g *(\ln (x))^{2}+i * y^{2}+k * y * \ln (x)\right.}{\left(1+b * \ln (x)+d * y+f *(\ln (x))^{2}+h * y^{2}+j * y * \ln (x)\right.} \\
\text { slop }=\frac{\left(a+c * \ln (x)+e * y+g *(\ln (x))^{2}+i * y^{2}+k * y * \ln (x)\right.}{\left(1+b * \ln (x)+d * y+f *(\ln (x))^{2}+h * y^{2}+j * y * \ln (x)\right.}
\end{gathered}
$$

where $a-j$ fitting coefficients.

The adjusted coefficients corresponding to these models are then listed in Table 4. The models were able to describe these continuous relationships almost perfectly $\left(R^{2}>0.99\right.$ in each case) when the predicted values were compared with those of the VDLUFA approach (Figure 6, right). 
Table 4. Fitted coefficients and their standard errors (in parentheses) of the mathematical models, as shown in Equations (7) and (8).

\begin{tabular}{|c|c|c|}
\hline Fitted & Dependent Variable & \\
\hline Coefficient & Intercept $^{1}$ & Slope ${ }^{1}$ \\
\hline a & $\begin{array}{c}-1.32 \\
\left(8.96 \times 10^{-2}\right)\end{array}$ & $\begin{array}{c}4.69 \times 10^{-1} \\
\left(2.93 \times 10^{-2}\right)\end{array}$ \\
\hline b & $\begin{array}{c}1.01 \times 10^{-1} \\
\left(1.80 \times 10^{-3}\right)\end{array}$ & $\begin{array}{c}8.20 \times 10^{-2} \\
\left(4.64 \times 10^{-3}\right)\end{array}$ \\
\hline c & $\begin{array}{c}-8.64 \\
\left(7.29 \times 10^{-2}\right)\end{array}$ & $\begin{array}{c}-1.12 \\
\left(2.72 \times 10^{-2}\right)\end{array}$ \\
\hline d & $\begin{array}{c}4.39 \times 10^{-4} \\
\left(5.96 \times 10^{-5}\right)\end{array}$ & $\begin{array}{l}-1.75 \times 10^{-3} \\
\left(1.57 \times 10^{-4}\right)\end{array}$ \\
\hline e & $\begin{array}{c}1.45 \times 10^{-1} \\
\left(1.50 \times 10^{-3}\right)\end{array}$ & $\begin{array}{c}2.24 \times 10^{-2} \\
\left(6.35 \times 10^{-4}\right)\end{array}$ \\
\hline $\mathbf{f}$ & $\begin{array}{c}1.70 \times 10^{-2} \\
\left(1.50 \times 10^{-4}\right)\end{array}$ & $\begin{array}{c}1.44 \times 10^{-2} \\
\left(3.83 \times 10^{-4}\right)\end{array}$ \\
\hline g & $\begin{array}{c}3.71 \times 10^{-2} \\
\left(4.79 \times 10^{-3}\right)\end{array}$ & $\begin{array}{c}1.28 \times 10^{-2} \\
\left(1.59 \times 10^{-3}\right)\end{array}$ \\
\hline $\mathbf{h}$ & $\begin{array}{l}-7.33 \times 10^{-7} \\
\left(1.47 \times 10^{-7}\right)\end{array}$ & $\begin{array}{c}7.71 \times 10^{-6} \\
\left(5.18 \times 10^{-7}\right)\end{array}$ \\
\hline $\mathbf{i}$ & $\begin{array}{l}-5.18 \times 10^{-4} \\
\left(5.22 \times 10^{-6}\right)\end{array}$ & $\begin{array}{l}-8.45 \times 10^{-5} \\
\left(2.40 \times 10^{-6}\right)\end{array}$ \\
\hline j & $\begin{array}{c}2.22 \times 10^{-4} \\
\left(5.89 \times 10^{-6}\right)\end{array}$ & $\begin{array}{c}2.08 \times 10^{-4} \\
\left(1.20 \times 10^{-5}\right)\end{array}$ \\
\hline k & $\begin{array}{c}3.64 \times 10^{-2} \\
\left(2.73 \times 10^{-4}\right)\end{array}$ & $\begin{array}{c}5.02 \times 10^{-3} \\
\left(9.57 \times 10^{-5}\right)\end{array}$ \\
\hline
\end{tabular}

\footnotetext{
${ }^{1}$ Intercept and slope of the relationship between the $\mathrm{pH}$ and lime demand.
}

To avoid excessive $\mathrm{CaO}$ applications, very high recommended $\mathrm{CaO}$ amounts should be split into two application rates. As recommended by the VDLUFA approach and mentioned in Section 2.1, the maximum amounts of a single $\mathrm{CaO}$ application (CaOmax) are merely soil texture dependent. By considering the soil texture classes by their corresponding MPDs, the relationship can be expressed by an exponential function that reads as follows (Figure 7):

$$
\mathrm{CaOmax}=(r-s) *(\exp (-t * \mathrm{MPD}))+s
$$

where $\mathrm{CaOmax}$ is the maximum $\mathrm{CaO}$ application rate $\left[\mathrm{Mg} \mathrm{ha}^{-1}\right], \mathrm{MPD}=$ mean particle diameter $\left[10^{-3} \mathrm{~m}\right]$ and $r, s$ and $t$ are dimensionless coefficients that have the following values (standard deviations): 8.7 (0.4), 2.7 (0.4) and 16.8 (3.2), respectively. 

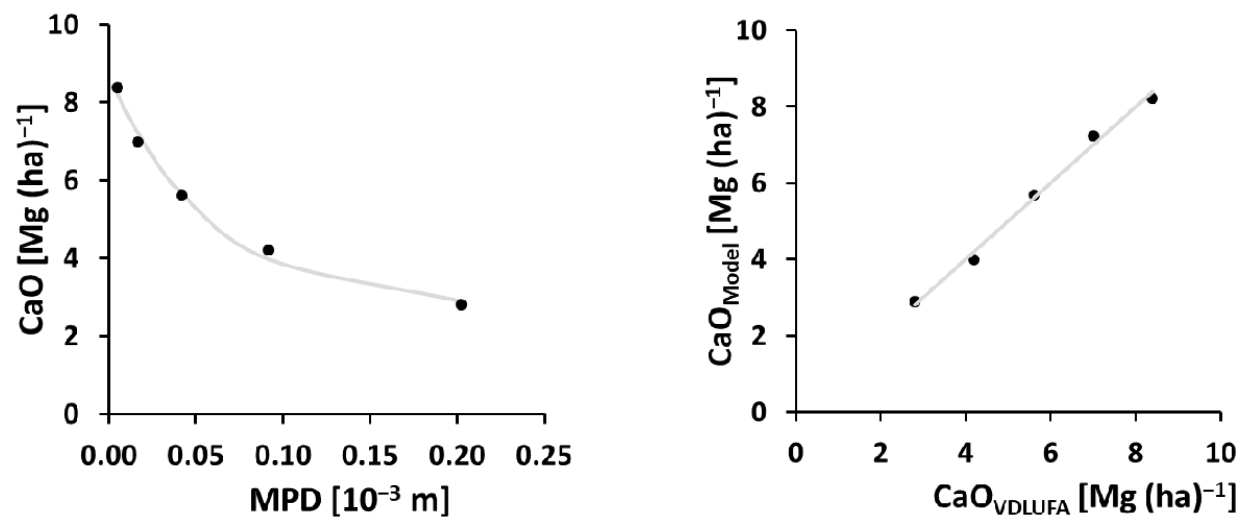

Figure 7. (Left): Maximum amount of a single $\mathrm{CaO}$ application $\left[\mathrm{Mg} \mathrm{ha}^{-1}\right]$ as recommended by the VDLUFA approach (dots) and calculated according to Equation (9) (line) always in relation to the mean particle diameter (MPD) [10 $\left.{ }^{-3} \mathrm{~m}\right]$. (Right): $\mathrm{CaO}$ amounts predicted by Equation (9) $\left(\mathrm{CaO}_{\text {Model }}\right)$ vs. observed VDLUFA $\left(\mathrm{CaO}_{\mathrm{VDLUFA}}\right) ; \mathrm{R}^{2}=0.992$.

Regarding the lime supply status $C$, the task was to relate the lime recommendation linearly to the $\mathrm{pH}$, decreasing from the lowest $\mathrm{CaO}$ amount recommended in lime supply status $\mathrm{B}$ to zero as recommended if the $\mathrm{pH}$ achieves lime supply status $\mathrm{D}$. Therefore, the upper $\mathrm{pH}$ limits of the lime supply statuses B (pHmax_B) and C (pHmax_C) were applied according to Equations (4) and (5). The minimum $\mathrm{CaO}$ demand (CaOmin_B) of lime supply level $\mathrm{B}$, which refers to its maximum $\mathrm{pH}$ ( $\left.\mathrm{pHmax}_{-} \mathrm{B}\right)$, can be calculated from Equations (2), (7) and (8). The $\mathrm{CaO}$ demand, which refers to the maximum $\mathrm{pH}$ of supply level $\mathrm{C}$ (pHmax_C), was set to $0 \mathrm{Mg} \mathrm{CaO} /$ ha. Consequently, the $\mathrm{CaO}$ demand $\left(\mathrm{CaO} \_\mathrm{C}\right)$ for any given $\mathrm{pH}$ (pHobs_C) will be calculated in our approach as follows:

$$
\mathrm{CaO} \_\mathrm{C}=\mathrm{CaOmin} \_\mathrm{B} *\left(\left(\mathrm{pHmax} \_\mathrm{C}-\mathrm{pHobs} \_\mathrm{C}\right)\right) /\left(\left(\mathrm{pHmax} \_\mathrm{C}-\mathrm{pHmax} \_\mathrm{B}\right)\right)
$$

\subsection{Model Validation}

Equation (2) can be used to describe the intercept and the slopes of the linear relationships between the soil's $\mathrm{pH}$ and lime demand for each of the 20 combinations of the soil texture and SOM classes. The dependencies of the intercepts (Equation (7)) and the slopes (Equation (8)) of these 20 linear functions from the MPD and SOM content are shown in Figure 6. Based on these dependencies, intercepts and slopes can be calculated steplessly for each combination between the $\mathrm{pH}$ value, soil texture (expressed as MPD, which is based on the clay, silt and sand content) and the SOM content within the data ranges given in Section 2.1.

To validate the stepless approach, the results were compared with the $\mathrm{CaO}$ recommendations provided by the VDLUFA look-up table system $(n=317)$ for $\mathrm{pH}$ values that correspond to lime supply statuses A and B (Figure 8). 


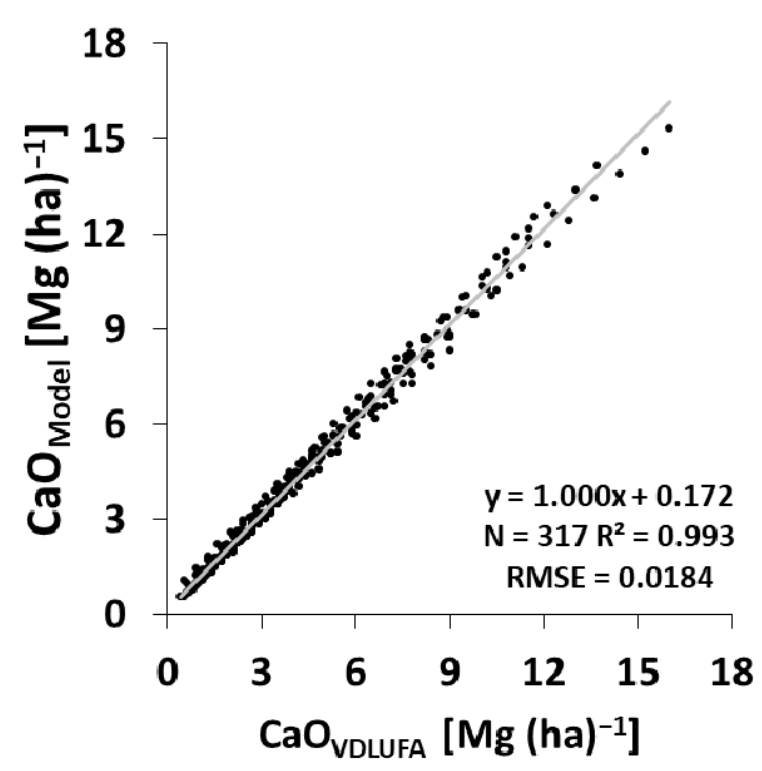

Figure 8. $\mathrm{CaO}$ amounts necessary to increase the $\mathrm{pH}$ value from a suboptimal range (lime supply statuses $\mathrm{A}$ and $\mathrm{B}$ ) to the optimum $\mathrm{pH}$ range (lime supply status $\mathrm{C}$ ), as recommended by the VDLUFA approach ( $\mathrm{CaO}_{\text {VDLUFA, }}$, see Figure 3$)$, in comparison to the $\mathrm{CaO}$ amounts predicted by the stepless approach $\left(\mathrm{CaO}_{\text {Model }}\right)$.

The calculation of the soil lime demand based on the results shown in Figure 6 resulted in excellent model performance. Less than $0.01 \%$ of the variability in the $\mathrm{CaO}$ amount which is recommended by the VDLUFA approach cannot be explained by the stepless approach

\section{Discussion}

The VDLUFA look-up table system [16] predicts the lime demand of soils as classbased, dependent on soil texture and the SOM. It is advantageous for farmers because they can apply it without calculations or special expert knowledge. On the other hand, the subdivision of the soil texture and the SOM into classes is a limitation if applied in a precision farming context. Using modern sensor-based soil mapping techniques, which can provide detailed, highly spatially resolved soil texture and SOM maps, a transformation from the class-based system into a continuous, stepless approach is necessary. As shown in our approach, the transformation from the class-based look-up table system to a continuous, stepless approach succeeded. In the results, we could explain more than $99 \%$ of the variability of the 317 recommended $\mathrm{CaO}$ amounts for lime supply statuses $\mathrm{A}$ and $\mathrm{B}$, differentiating into five soil texture classes and four organic matter classes. Regarding the chosen mathematical models, our focus was to predict these 317 recommended $\mathrm{CaO}$ amounts as exactly as possible by the models allying to the continuous approach-without local minima and maxima and within the data range. Neither reducing the number of fitted model parameters nor testing for their level of significance were criteria for selecting the respective model.

Compared to other international approaches $[13,27,28]$, the German VDLUFA agricultural liming recommendation is the most detailed and considers not only the influence of $\mathrm{pH}$ but also the effects of soil texture and SOM. Therefore, the applied methodology may be of broader interest, especially because algorithms that are needed in the context of present-day requirements of precision farming should be continuous and stepless. However, to derive the maximum benefit from the continuous liming approach, the following problems that are obvious within the chain-from the primary data acquisition $(\mathrm{pH}$, soil texture, SOM) to the final lime spreading-need to be considered:

i. The finger texturing method is usually applied for agricultural purposes because the exact estimation of the soil texture by sieving and sedimentation analyses is timeand cost-intensive. However, Stocker and Walthert [29] reported that solely $68 \%$, 
$31 \%$ and $56 \%$ of clay, silt and sand variability, respectively, could be explained by the finger texturing method (predicted by sieving and sedimentation analyses). They took more than 11,000 soil samples from approximately 90 Swiss forest sites from six depth levels down to $1.5 \mathrm{~m}$. This rather imprecise soil texture determination can lead to unrealistic and severe differences in the lime application recommendations of management units [19].

ii. In the past, management zones of 3 to 5 ha with assumed homogenous soil were chosen, since equal zones generally require the same liming rates and provide reasonable sizes in terms of the application equipment and sampling rates [30]. However, the creation of those management zones neglects the variation in the soil texture, SOM and the actual $\mathrm{pH}$ within the management units. To provide reliable soil parameters for lime management at a higher spatial resolution and low costs, on-the-go soil sensor systems, such as the Geophilus [31] and the Veris $\mathrm{pH}$ manager [32], are appropriate solutions. Meyer et al. [19] used the mentioned sensor systems in combination with targeted soil samples that were taken for sensor calibrations by analyzing the soil $\mathrm{pH}, \mathrm{SOM}$ and soil texture with standardized laboratory methods. Finally, they produced $2 \times 2 \mathrm{~m}$ maps of the actual soil acidity $(\mathrm{pH}), \mathrm{SOM}$ and soil texture (clay, silt, and sand). Bönecke et al. [17] used these generated soil maps and the stepless algorithm to successfully produce variable rate lime application maps. They compared the variable liming rates with a standard uniform liming approach and found that $63 \%$ of the field would be over-fertilized by approximately $12 \mathrm{Mg}$ of lime, $6 \%$ would receive approximately $6 \mathrm{Mg}$ too little lime and $31 \%$ would still be adequately limed under the uniform liming approach.

iii. As mentioned above, reference or targeted soil sampling is necessary to calibrate sensor data that are not causally related to the agronomic parameters used to make management decisions. In practice, the determination of sampling locations is almost subjective. According to Adamchuk et al. [33], three criteria should be considered: (a) targeted samples have to cover the entire range of the sensor data, (b) within a radius of $30 \mathrm{~m}$ around the reference sampling point, the soil should be spatially homogeneous and (c) the targeted sampling locations should be well distributed throughout the area of investigation. To the best of our knowledge, a reliable automated approach to determine the targeted sampling locations built up on these three criteria is still missing.

iv. Regarding fertilizer applicators, Lawrence $[21,34,35]$ reported that, although variable rate technologies have been demonstrated to satisfactorily operate the actual performance of the fertilizer, spreading machinery is often shown to be inadequate. A similar assessment was given by Holmes and Jiang [36] who argued that the current fertilizer spreading equipment does not provide the accuracy needed to undertake variable rate liming trials. This problem is further aggravated because the two main variable rate fertilizer application techniques are the application of liquid and granulose products. Granular lime fertilizers are available, but are more expensive and therefore usually less applied.

Regardless of the presented problems, increasing attention is being paid to small-scale site-adapted liming by farmers, not least because it is associated with three kinds of benefits: agronomical, economic and environmental.

Supplementary Materials: The following are available online at https: / www.mdpi.com/article / 10.3390 /agronomy 11040785 /s1, The algorithm to determine $\mathrm{CaO}$ amounts as stepless approach is provided as R-script of the free software environment for statistical computing and graphics $\mathrm{R}$ (version 4.0.2). 
Author Contributions: Conceptualization, J.R.; methodology, J.R.; software, E.B., S.M.; validation, J.R., E.B., S.M.; formal analysis, J.R., E.B., S.M.; investigation, J.R., E.B., S.M.; resources, J.R.; data curation, J.R., E.B., S.M.; writing-original draft preparation, J.R.; writing—review and editing, J.R., E.B., S.M.; visualization, J.R., E.B., S.M.; supervision, J.R.; and project administration, J.R. All authors have read and agreed to the published version of the manuscript.

Funding: The stepless algorithm was adapted and finalized within the project 'pH-BB: precision liming in Brandenburg' (http:/ / ph-bb.com, accessed on 5 January 2020) which is part of the agricultural European Innovation Partnership program (EIP-AGRI) to improve agricultural productivity and sustainability (Project No.: 204016000014/80168341). The program is funded by the European Agricultural Fund for Rural Development of the European Commission and by the Ministry of Rural Development, Environment and Agriculture of the state Brandenburg in Germany.

Institutional Review Board Statement: Not applicable.

Informed Consent Statement: Not applicable.

Data Availability Statement: The data presented in this study are openly available in [16], in German language.

Acknowledgments: We want to thank W. Olfs, FH Osnabrück, and the three anonymous reviewers for their helpful comments on the manuscript.

Conflicts of Interest: The authors declare no conflict of interest.

\section{References}

1. Pierce, F.J.; Nowak, P. Aspects of Precision Agriculture. In Advances in Agronomy; Elsevier: Amsterdam, The Netherlands, 1999; Volume 67, pp. 1-85.

2. Basso, B.; Cammarano, D.; Fiorentino, C.; Ritchie, J.T. Wheat yield response to spatially variable nitrogen fertilizer in Mediterranean environment. Eur. J. Agron. 2013, 51, 65-70. [CrossRef]

3. Robertson, M.J.; Llewellyn, R.S.; Mandel, R.; Lawes, R.; Bramley, R.G.V.; Swift, L.; Metz, N.; O'Callaghan, C. Adoption of variable rate fertiliser application in the Australian grains industry: Status, issues and prospects. Precis. Agric. 2012, 13, 181-199. [CrossRef]

4. Robert, P.C. Precision agriculture: A challenge for crop nutrition management. In Progress in Plant Nutrition: Plenary Lec-Tures of the XIV International Plant Nutrition Colloquium: Food Security and Sustainability of Agro-ecosystems through Basic and Applied Research; Horst, W.J., Ed.; Kluwer Academic Publishers: Dordrecht, The Netherlands, 2010; pp. 143-149. ISBN 978-90-481-6191-1.

5. Moharana, P.C.; Jena, R.K.; Pradhan, U.K.; Nogiya, M.; Tailor, B.L.; Singh, R.S.; Singh, S.K. Geostatistical and fuzzy clustering approach for delineation of site-specific management zones and yield-limiting factors in irrigated hot arid environment of India. Precis. Agric. 2019, 21, 426-448. [CrossRef]

6. Moral, F.J.; Rebollo, F.J.; Serrano, J.M. Delineating site-specific management zones on pasture soil using a probabilistic and objective model and geostatistical techniques. Precis. Agric. 2019, 21, 620-636. [CrossRef]

7. Wang, X.; Miao, Y.; Dong, R.; Chen, Z.; Kusnierek, K.; Mi, G.; Mulla, D.J. Economic Optimal Nitrogen Rate Variability of Maize in Response to Soil and Weather Conditions: Implications for Site-Specific Nitrogen Management. Agronomy 2020, $10,1237$. [CrossRef]

8. Basso, B.; Dumont, B.; Cammarano, D.; Pezzuolo, A.; Marinello, F.; Sartori, L. Environmental and economic benefits of variable rate nitrogen fertilization in a nitrate vulnerable zone. Sci. Total Environ. 2016, 545-546, 227-235. [CrossRef]

9. Nawar, S.; Corstanje, R.; Halcro, G.; Mulla, D.; Mouazen, A.M. Delineation of Soil Management Zones for Variable-Rate Fertilization. In Advances in Agronomy; Elsevier: Amsterdam, The Netherlands, 2017; pp. 175-245.

10. Vogel, S.; Bönecke, E.; Kling, C.; Kramer, E.; Lück, K.; Nagel, A.; Philipp, G.; Rühlmann, J.; Schröter, I.; Gebbers, R. Base Neutralizing Capacity of Agricultural Soils in a Quaternary Landscape of North-East Germany and Its Relationship to Best Management Practices in Lime Requirement Determination. Agronomy 2020, 10, 877. [CrossRef]

11. Schilling, G.; Ansorge, H. Pflanzenernährung und Düngung: 164 Tabellen (Plant Nutrition and Fertilization: 164 Tables); VEB Deutscher Landwirtschaftsverlag: Berlin, Germany, 1982. (In German)

12. Blume, H.-P.; Brümmer, G.W.; Horn, R.; Kandeler, E.; Kögel-Knabner, I.; Kretzschmar, R.; Stahr, K.; Wilke, B.-M.; ThieleBruhn, S.; Welp, G. Scheffer/Schachtschabel: Lehrbuch der Bodenkunde (Scheffer/Schachtschabel: Textbook of Soil Science); Springer: Berlin/Heidelberg, Germany, 2010.

13. Goulding, K.W.T. Soil acidification and the importance of liming agricultural soils with particular reference to the United Kingdom. Soil Use Manag. 2016, 32, 390-399. [CrossRef]

14. Kerschberger, M.; Deller, B.; Hege, U.; Heyn, J.; Kape, H.E.; Krause, O.; Pollehn, J.; Rex, M.J.; Severin, K. Bestimmung des Kalkbedarfs von Acker-Und Grünlandböden (Determination of the Lime Requirement of Arable and Grassland Soils); VDLUFA-Verlag: Speyer, Germany, 2000. 
15. Kerschberger, M.; Marks, G. Einstellung und Erhaltung eines standorttypischen optimalen pH-Wertes im Boden-Grundvoraussetzung fur eine effektive und umweltvertragliche Pflanzenproduktion (Setting and maintaining a site-specific optimum $\mathrm{pH}$ value in the soil-a basic requirement for effective and environmentally compatible plant production). Berichte über Landwirtschaft 2007, 85 , 56-77.

16. Von Wulffen, U.; Roschke, M.; Kape, H.-E. Richtwerte für die Untersuchung und Beratung Sowie zur Fachlichen Umsetzung der Düngeverordnung (DüV): Gemeinsame Hinweise der Länder Brandenburg, Mecklenburg-Vorpommern und Sachsen-Anhalt (Guide values for the Examination and Advice as Well as for the Professional Implementation of the Fertilizer Ordinance (DüV): Joint Information from the States of Brandenburg, Mecklenburg-Western Pomerania and Saxony-Anhalt); LLFG: Güterfelde, Germany, 2008.

17. Bönecke, E.; Meyer, S.; Vogel, S.; Schröter, I.; Gebbers, R.; Kling, C.; Kramer, E.; Lück, K.; Nagel, A.; Philipp, G.; et al. Guidelines for precise lime management based on high-resolution soil $\mathrm{pH}$, texture and SOM maps generated from proximal soil sensing data. Precis. Agric. 2020, 1-31. [CrossRef]

18. Boenecke, E.; Lueck, E.; Ruehlmann, J.; Gruendling, R.; Franko, U. Determining the within-field yield variability from seasonally changing soil conditions. Precis. Agric. 2018, 19, 750-769. [CrossRef]

19. Meyer, S.; Kling, C.; Vogel, S.; Schröter, I.; Nagel, A.; Kramer, E.; Gebbers, R.; Philipp, G.; Lück, K.; Gerlach, F.; et al. Creating soil texture maps for precision liming using electrical resistivity and gamma ray mapping. In Precision Agriculture'19; Wageningen Academic Publishers: Wageningen, The Netherlands, 2019.

20. Haynes, R.; Naidu, R. Influence of lime, fertilizer and manure applications on soil organic matter content and soil physical conditions: A review. Nutr. Cycl. Agroecosyst. 1998, 51, 123-137. [CrossRef]

21. Lawrence, H.G. Adoption of Precision Agriculture Technologies for Fertiliser Placement in New Zealand. Ph.D. Thesis, Massey University, Palmerston North, New Zealand, 2007.

22. Fulton, J.P.; Shearer, S.A.; Chabra, G.; Higgins, S.F. Performance Assessment and Model Development of A Variable-Rate, Spinner-Disc Fertilizer Applicator. Trans. ASAE 2001, 44, 1071. [CrossRef]

23. Voon Wulffen, H.-U.; Horn, D.; Lorenz, F.; Müller, R.; Müller, T.; Münchhoff, K.; Pihl, U.; Weber, A. DLG-Merkblatt 456-Hinweise zur Kalkdüngung (DLG-Leaflet 456-Notes on Lime Fertilization), 1st ed.; DLG e. V.: Frankfurt am Main, Germany, 2020.

24. Shiozawa, S.; Campbell, G.S. On The Calculation of Mean Particle Diameter and Standard Deviation from Sand, Silt, and Clay Fractions. Soil Sci. 1991, 152, 427-431. [CrossRef]

25. Shirazi, M.A.; Boersma, L.; Hart, J.W. A Unifying Quantitative Analysis of Soil Texture: Improvement of Precision and Extension of Scale. Soil Sci. Soc. Am. J. 1988, 52, 181-190. [CrossRef]

26. R Core Team. R: A Language and Environment for Statistical Computing; R Foundation for Statistical Computing: Vienna, Austria, 2018. Available online: https:/ / www.R-project.org (accessed on 17 August 2020).

27. Baumgarten, A.; Berthold, H.; Buchgraber, K.; Dersch, G.; Egger, H.; Egger, R.; Eigner, H.; Frank, P.; Gerzabek, M.; Hölzl, F.X. Richtlinie für die Sachgerechte Düngung im Ackerbau und Grünland (Guideline for Appropriate Fertilization in Arable Farming and Grassland); BMLFUW: Wien, Austria, 2017.

28. Vitosh, M.L.; Johnson, J.W.; Mengel, D.B. Tri-State Fertilizer Recommendations for Corn, Soybean, Wheat and Alfalfa; Extension Bulletin; Ohio State University: Columbus, OH, USA, 1995; E-2567. Available online: http:/ / ohioline.osu.edu/e2567/ (accessed on 23 January 2021).

29. Stocker, N.; Walthert, L. Böden und Wasserhaushalt von Wäldern und Waldstandorten der Schweiz unter heutigem und zukünftigem Klima (BOWA-CH)-Datengrundlage und Datenharmonisierung. (Soils and Water Balance of Forests and Forest Locations in Switzerland under Current and Future Climates—Data Basis and Data Harmonization) Projektinterner Bericht (Internal Project Report); ETH-Zurich: Zurich, Switzerland, 2013.

30. Borgelt, S.C.; Searcy, S.; Stout, B.A.; Mulla, D.J. Spatially Variable Liming Rates: A Method for Determination. Trans. ASAE 1994, 37, 1499-1507. [CrossRef]

31. Lueck, E.; Ruehlmann, J. Resistivity mapping with GEOPHILUS ELECTRICUS-Information about lateral and vertical soil heterogeneity. Geoderma 2013, 199, 2-11. [CrossRef]

32. Schirrmann, M.; Gebbers, R.; Kramer, E.; Seidel, J. Soil pH Mapping with an On-The-Go Sensor. Sensors 2011, 11, 573-598. [CrossRef]

33. Adamchuk, V.I.; Rossel, R.A.V.; Marx, D.B.; Samal, A.K. Using targeted sampling to process multivariate soil sensing data. Geoderma 2011, 163, 63-73. [CrossRef]

34. Lawrence, H.G.; Yule, I.J. A GIS Methodology to Calculate In-Field Dispersion of Fertilizer from a Spinning-Disc Spreader. Trans. ASABE 2007, 50, 379-387. [CrossRef]

35. Lawrence, H.G.; Yule, I.J.; Coetzee, M.G. Development of an Image-Processing Method to Assess Spreader Performance. Trans. ASABE 2007, 50, 397-407. [CrossRef]

36. Holmes, A.W.; Jiang, G. Effect of variable rate lime application on autumn sown barley performance. Agron. N. Z. 2017, 47, 37-45. 